\title{
Hvor skal du føde?
}

I spalten Internasjonal medisin hører vi stadig om hvor farlig fødsel er både for mor og barn. Trygg fødselsomsorg og hjelp under fødselen er fortsatt ingen selvfølge overalt. I Tidsskriftet nr. 7/1940 (Tidsskr Nor Lægeforen 1940; 60: 311 -9) blir vi påminnet om at fødselsomsorg ikke var en helt enkel diskusjon her hjemme heller.

\section{Om innleggelse av fødende i sykehus. Av O. Bugge-Asperheim, Molde.}

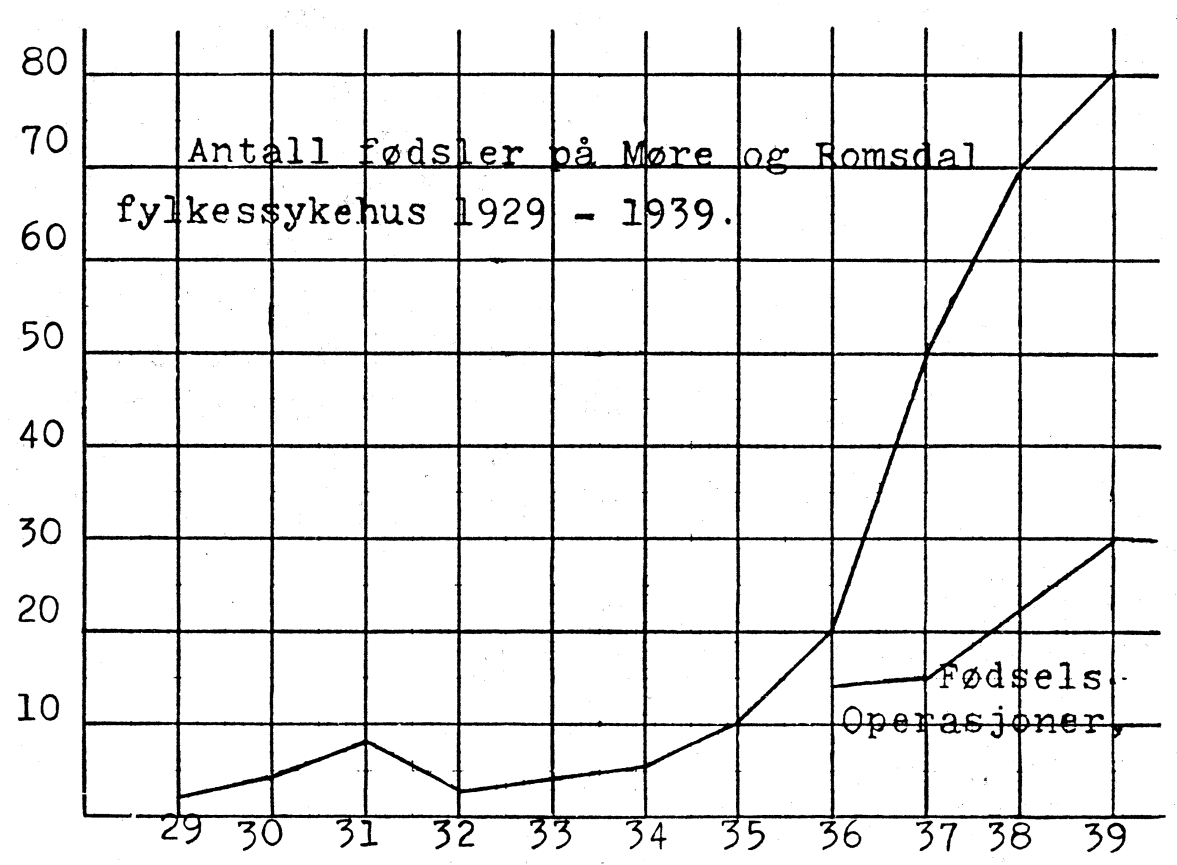

Fig. 1.

Spørsmålet om i hvilken utstrekning fødende bør innlegges i sykehus i vårt vidstrakte land er brennende aktuelt for mange landsdelers vedkommende, således også hos oss. Derfor holdt jeg et kort foredrag om vår fødeavdelings virksomhet for en del læger for en tid siden og mener at det kanskje kan påregne mer almen interesse.

Det blir ofte så at sykehuslægene anser det ønskelig at en del fødsler innlegges i sykehus, mens mange praktiserende læger mener at den fødende vel så godt kan ligge hjemme. Dog tror jeg meningsforskjellen blant praktiserende læger og sykehuslæger i den henseende blir mindre etterhvert, fordi de fleste læger føler det som en lettelse når en mer komplisert fødsel kommer i sykehus.

Blant publikum er det igjen to kategorier - alle de gamle konene som har født ti barn hjemme og ikke kan forstå hvorfor neste generasjon må føde i sykehus, og på den annen side de fødende selv, som i stigende utstrekning ønsker å føde i sykehus. Årsaken til dette siste ligger både i den økede sikkerhet mot mulige komplikasjoner under fødselen og det mer systematiske stell i barselsengen, samt at det er meget makeligere fordi hun slipper å tenke på alle huslige gjøremål osv.

En tredje side av saken er den økonomiske; det er særlig sykekassene det går ut over, idet fødselen i sykehuset i alminnelighet utover landet vil falle dyrere for sykekassen enn hjemmefødsler, hvis lægehjelp ikke viser seg påkrevet. Det er dette siste moment som dessverre enda er den avgjørende hindring for de fødende til å legge seg inn i sykehus i større utstrekning. 